\title{
Aktywizowanie rozwoju sprawności słuchania w języku polskim jako ojczystym
}

\author{
Activating listening comprehension skills \\ in Polish language as mother tongue
}

Summary: The aim of the present article is to present the typology of listening comprehension skills activated during Polish language lessons. What the author claims is that in Polish school two types of listening co-exist, namely: natural and activated. The former resembles conditions of natural communication, since a student assumes the role of text recipient, whereas the latter is a process of teaching the skills of listening comprehension. Based on questions and instructions elicited from selected school handbooks shows in what way the activated type of listening comprehension is taught as a part of Polish as a mother tongue lessons.

Keywords: listening, typology, questions, instructions, Polish as a mother tongue

Podejmując temat umiejętności słuchania w szkole, warto zwrócić uwagę na jej dwa wymiary: naturalny (umiejętność słuchania jako narzędzie kształcenia w sytuacji lekcyjnej) i aktywizowany (umiejętność słuchania jako treść kształcenia, składowa kompetencji komunikacyjnej). Pierwszy wymiar przypomina naturalne warunki porozumiewania się, natomiast drugi odnosi się do procesu nauczania percepcji słuchowej. Dwa wymiary słuchania w edukacji szkolnej współistnieją, ale znacznie się od siebie różnią. Ważne jest podkreślenie tych różnic.

W glottodydaktyce słuchanie naturalne nazywa się słuchaniem ekstensywnym. Definiuje się je jako naturalną reakcję organizmu na tekst, który zawiera ważną dla odbiorcy informację lub jego percepcja sprawia mu przyjem- 
ność1. Lekcja szkolna jest specyficzną sytuacją komunikacyjną, uczestniczą w niej uczniowie i nauczyciel, pełniący jednocześnie dwie funkcje: nadawcy i odbiorcy tekstu. Wykorzystują oni wszystkie umiejętności komunikacyjne, czyli mówienie, pisanie, czytanie i słuchanie. Zwykle jedna z wymienionych sprawności dominuje w kolejnych fazach lekcji. Ponieważ lekcja przyjmuje formę dialogu, można wnioskować, że mówienie i słuchanie są umiejętnościami najczęściej wykorzystywanymi zarówno przez uczniów, jak i nauczycieli. Tezę tę potwierdzają badania, jakie przeprowadziła Krystyna Wojtczuk. Zachowania językowe nauczycieli w sytuacji lekcyjnej to: pytania, żądania, informowanie, wywoływanie do odpowiedzi, ocenianie, korygowanie i powtarzanie wypowiedzi uczniowskich ${ }^{2}$. Wszystkie one wymagają od uczniów uważnego słuchania. Ponadto pytania, żądania i wywoływanie do odpowiedzi implikują konieczność reakcji ucznia w postaci wypowiedzi mówionej lub pisanej.

Spośród czterech sprawności komunikacyjnych, które kształci się w polskiej szkole, nauczyciele najczęściej mówią, natomiast uczniowie słuchają, co wiąże się z asymetrią ról społecznych $\mathrm{w}$ akcie komunikacji szkolnej. Potwierdzają to badania ankietowe przeprowadzone przez Małgorzatę Mądry-Kupiec ${ }^{3}$. Wynika z nich, że nauczyciele poświęcają około $30-70 \%$ czasu lekcyjnego na mówienie do uczniów, tj. od około 13 do 30 minut $^{4}$, przy czym mówienie nauczycieli najczęściej zajmuje około $30-50 \%$ czasu, czyli około $13-23$ minut $^{5}$. Z tych samych badań wynika, że uczniowie wykorzystują do $20 \%$ czasu lekcyjnego na mówienie, czyli do 9 minut $^{6}$, a $50-70 \%$ czasu przeznaczają na słuchanie ${ }^{7}$. Ponieważ sytuacja lekcyjna przypomina naturalną sytuację komunikacyjną, percepcja komunikatów mówionych nie jest sterowana. Odbiór informacji przekazywanych drogą foniczną warunkują między innymi motywacja, dyspozycyjność psychiczna i zdolności intelektualne ucznia ${ }^{8}$. W związku z tym

1 Zob. A. Howatt, J. Dakin: Materiały do pracy w laboratorium językowym. Tłum. E. Moszczak. W: Kurs edynburski językoznawstwa stosowanego. T. 2: Techniki w językoznawstwie stosowanym. Red. J.P.B. Allen, S. Pit Corder, A. Davies. Warszawa 1983, s. 84-115.

${ }^{2}$ Zob. K. Wojtczuk: Zachowania językowe nauczycieli w sytuacji lekcji szkolnej. Siedlce 1996, s. 71.

${ }^{3}$ Zob. M. Mądry-Kupiec: Komunikacja werbalna nauczyciela i ucznia na lekcji. Kraków 2011.

${ }^{4} \mathrm{~W}$ badaniach brało udział 152 nauczycieli, z czego 63 ankietowanych $(41,45 \%)$ deklarowało wartość od 30 do 50\% czasu przeznaczonego na mówienie, a $45(29,61 \%)$ - od 50 do $70 \%$ czasu lekcyjnego.

5 Zob. M. Mądry-Kupiec: Komunikacja werbalna..., s. 52.

${ }^{6}$ W badaniach brało udział 242 uczniów, z czego 93 (38,43\%) ankietowanych deklarowało wartość mniej niż 10\% czasu przeznaczonego na mówienie, a $78(32,23 \%)-$ od $10-20 \%$ czasu lekcyjnego.

7 Wartość wskazało 90 ankietowanych (37,5\%). Drugim najczęściej wybieranym przedziałem było ,powyżej 70\%”-61 ankietowanych.

${ }^{8}$ Zob. J.-L. Aubert: Naucz swoje dziecko stuchać. Odpowiedzi na pytania najczęściej zadawane przez rodziców. Tłum. A. Wróblewski. Warszawa 2007, s. 129. 
nie wiadomo, czy słuchanie naturalne jest efektywne. Można przypuszczać, że nie, ponieważ generalnie efektywność odbioru słuchowego ocenia się jedynie na $25 \%$, co oznacza, że dziesięciominutowa rozmowa jest zapamiętywana i wykorzystywana w wymiarze 2,5 minuty9 . Dzieje się tak, gdyż na efektywną percepcję wypowiedzi wpływa wiele czynników ${ }^{10}$, dlatego tak ważne znaczenie ma biegłe opanowanie umiejętności słuchania przez uczniów, którzy w ramach edukacji szkolnej powinni stać się biegłymi słuchaczami — osobami:

- mającymi motywację do efektywnego słuchania (chcącymi efektywnie słuchać w różnych sytuacjach);

- mającymi odpowiednią wiedzę i wyposażonymi w przydatne umiejętności, dzięki którym będą wiedziały, co mają zrobić, aby efektywnie słuchać;

— wykazującymi zdolność efektywnego słuchania w różnych sytuacjach komunikacyjnych (także w tych niesprzyjających odbiorowi tekstu) ${ }^{11}$.

Między innymi z tego powodu na lekcjach języka polskiego od 1999 roku rozpoczęto kształcenie umiejętności słuchania, tzn. zwrócono uwagę na potrzebę wprowadzenia do podstawy programowej słuchania aktywizowanego, związanego z procesem nauczania percepcji słuchowej, w czasie którego uczeń jest przygotowywany do roli odbiorcy w życiu codziennym. W glottodydaktyce ten typ słuchania (zwany intensywnym) definiuje się jako sprawność dokładnego zrozumienia tekstu bądź zwracanie uwagi na poszczególne elementy języka (słownictwo, struktury gramatyczne lub wymowę) $)^{12}$.

Słuchanie aktywizowane w przeciwieństwie do naturalnego jest ściśle zaplanowane, składa się z trzech etapów:

— instrukcji — pytania lub polecenia (przekazywanego drogą foniczną albo graficzną);

— percepcji — odbioru słuchowego wypowiedzi, jej analizy i interpretacji;

— reakcji — werbalnej (ustnej lub pisemnej) albo niewerbalnej odpowiedzi na postawione pytania, świadczącej o poziomie zrozumienia treści wypowiedzi (na poziomie lokalnym i globalnym), selekcji informacji oraz stopnia ich zapamiętania ${ }^{13}$.

Ponieważ, jak stwierdza Hanna Komorowska, odbiorca słucha, gdy stoi przed nim konkretne zadanie ${ }^{14}$, najważniejszym etapem procesu kształcenia

${ }^{9}$ Zob. E. Lipińska: Stuchanie - sprawność zaniedbywana. „Przegląd Polonijny” 1994, z. 4 , s. 75.

${ }^{10}$ Zob. ibidem, s. 78. Por. S.P. Morreale, B.H. Spitzberg, J.K. Barge: Komunikacja między ludźmi. Motywacja, wiedza i umiejętności. Tłum. P. Izdebski, A. Jaworska-Surma, D. Kobylińska. Warszawa 2007, s. 220-226.

11 Zob. E. Lipińska: Stuchanie - sprawność zaniedbana..., s. 75-89.

12 Zob. A. How att, J. Dakin: Materiaty do pracy..., s. 85-88.

${ }_{13}$ Zob. E. Lipińska: Stuchanie - sprawność zaniedbana..., s. 76.

${ }^{14}$ Zob. H. Komorow ska: Metodyka nauczania języków obcych. Warszawa 1999, s. 175. 
percepcji słuchowej jest instrukcja, która ukierunkowuje odbiór tekstów i wyznacza jego zamierzone efekty. Zdaniem Jolanty Nocoń, to pytania i polecenia wskazują, jaką czynność powinien wykonać adresat ćwiczeń, są środkiem służącym nauczycielom do sterowania uczeniem się przez działanie ${ }^{15}$, dlatego też można przyjąć, że dzięki pytaniom i poleceniom kształci się słuchanie aktywizowane na lekcjach języka polskiego. Celem niniejszego artykułu jest zaproponowanie typologii umiejętności słuchania aktywizowanego na języku polskim jako ojczystym ${ }^{16}$.

W ramach edukacji polonistycznej aktywizacja umiejętności słuchania przebiega na kilku poziomach. Na umiejętność odbioru tekstu mówionego w języku polskim jako ojczystym składają się dwa typy percepcji słuchowej, tj. na poziomie dźwięku (odbiór dźwięków mowy, otoczenia, muzycznych) oraz komunikatu (odbiór wypowiedzi). Rozwój percepcji słuchowej na pierwszym poziomie służy poznaniu i zrozumieniu dźwiękowej warstwy języka oraz wyodrębnianiu i interpretowaniu dźwięków: muzycznych, otoczenia, mowy. Słuchanie na poziomie tekstu ma natomiast na celu usprawnienie rozumienia różnego rodzajuwypowiedzi, ich analizy, interpretacji i oceny. W ramach doskonalenia umiejętności słuchowego odbioru materiału dźwiękowego, zarówno na poziomie dźwięku, jak i tekstu, rozwija się szczegółowe sprawności percepcyjne, które można przedstawić $\mathrm{w}$ formie typologii kształcenia słuchania $\mathrm{w}$ języku polskim jako ojczystym (schemat 1.).

Pierwszy rodzaj słuchania, słuchanie fonematyczne, polega na odbiorze dźwięków otoczenia, muzycznych i mowy (warstwy segmentalnej i suprasegmentalnej języka). Praca nad słuchaniem fonematycznym zmierza do doskonalenia świadomości fonologicznej — świadomości dźwięków mowy, intonacji, rymów, podobieństwa dźwięków, sylab i fonemów ${ }^{17}$. Słuchanie fonematyczne dzieli się na dwa typy: słuchanie analityczne oraz interpretacyjne.

Słuchanie analityczne jest najbardziej elementarną sprawnością percepcyjną, opierającą się wyłącznie na wyodrębnieniu, identyfikacji i analizie dźwięków. W edukacji polonistycznej doskonalenie tego typu słuchania utożsamia się przede wszystkim z pracą nad słuchem fonematycznym, z uczeniem fonetyki i fonologii, gdyż zagadnienia te jako pierwsze pozwalają użytkownikom języka poznać i zrozumieć dźwiękową warstwę języka. Kształcenie słuchania analitycznego na lekcjach języka polskiego dotyczy w szczególności:

15 Zob. J. Nocoń: Polecenia i pytania w podręcznikach do nauki o języku. Opole 1997, s. 52.

16 Typologia została opracowana na podstawie pytań i poleceń wyodrębnionych z wybranych podręczników szkolnych do języka polskiego.

17 Zob. Dźwięki mowy. Program kształtowania świadomości fonologicznej dla dzieci przedszkolnych i szkolnych. Red. A. Mauer. Kraków 2009, s. 11-12. 


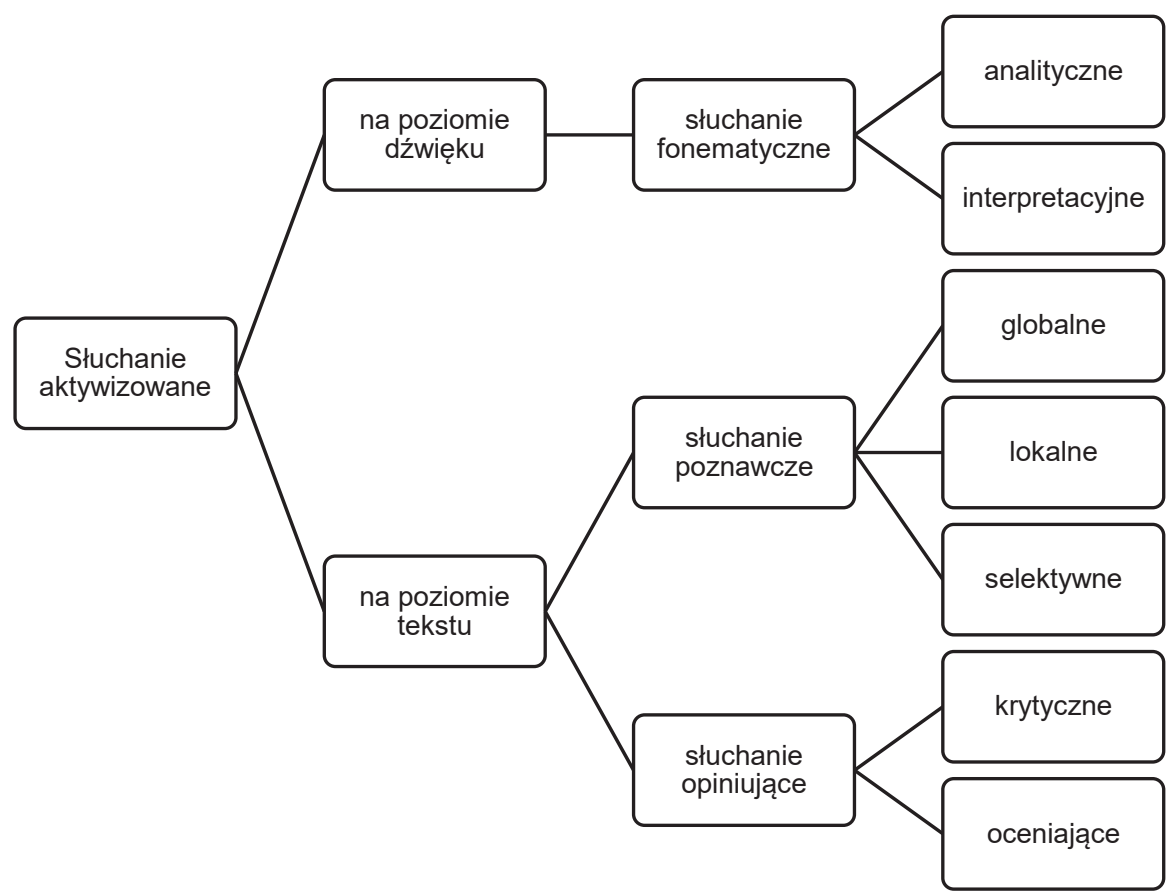

Schemat 1. Typologia umiejętności słuchania. Propozycja autorska

- wyodrębniania, różnicowania, analizowania dźwięków mowy, a także ich dekodowania (zamiany głosek na litery i odwrotnie), np.:

Przeczytaj głośno podane sentencje. Powiedz, jakie głoski wymawiasz zamiast tych, które zapisano wyróżnionymi literami. Za każdym razem określ kierunek upodobnienia ${ }^{18}$;

— rozpoznawania elementów prozodycznych wypowiedzi, np.:

Przeczytaj głośno podany fragment tekstu i sprawdź, czy odpowiednio zaznaczono pauzy. Popraw dostrzeżone błędy ${ }^{19}$;

— rozpoznawania fonetycznych środków stylistycznych w tekstach literackich, np.:

18 J. Kościerzyńska, M. Chmiel, M. Szulc, A. Gorzałczyńska-Mróz: Nowe słowa na start! Podręcznik do języka polskiego dla klasy ósmej szkoły podstawowej. Warszawa 2018, s. 253.

${ }_{19}$ M. Chmiel, E. Kostrzewa: Ponad stowami. Podręcznik do języka polskiego dla liceum i technikum. Zakres podstawowy i rozszerzony. Klasa 1. Część 1. Warszawa 2012, s. 74. 
Poszukaj w wierszu przykładów instrumentacji głoskowej. Przeczytaj utwór na głos, starając się podkreślić jego brzmienie ${ }^{20}$.

Słuchanie interpretacyjne jest bardziej zaawansowaną umiejętnością niż słuchanie analityczne, ponieważ polega na interpretowaniu dźwięków, określaniu funkcji, jakie pełnią w tekście kultury, oraz efektów, jakie wywołują (komunikacyjnych, estetycznych, emocjonalnych itp.). Wymaga od uczniów sfunkcjonalizowanej wiedzy z zakresu poetyki, kultury żywego słowa (estetyki językowej), jak również komunikacji niewerbalnej. Słuchanie interpretacyjne rozwija się w ramach pracy nad:

— dostrzeganiem i analizowaniem dźwiękowej warstwy języka w czasie odbioru tekstów mówionych (szeroko rozumianymi zagadnieniami kultury żywego słowa, między innymi wpływu poprawności językowej na wizerunek nadawcy; głosu jako narzędzia wartościowania rzeczywistości), np.:

Wystuchajcie ponownie utworu „Bursztynowa korona” i porozmawiajcie o tym, jakich sposobów użyła osoba czytajaca legendę, by zaciekawić stuchaczy? ${ }^{21}$;

— interpretowaniem utworów muzycznych, np.:

Postuchaj utworu „Popotudnie fauna” Claude'a Debussy'ego (zob. s. 236). Postaraj się wyjaśnić, na czym polega impresjonizm tej muzyki? ${ }^{22}$;

- interpretowaniem warstwy dźwiękowej w przekazach audialnych i tekstach audiowizualnych (filmie, spektaklu, słuchowisku radiowym itp.), np.:

W filmie ważna rolę odgrywa muzyka. Jak zbudowat warstwę dźwiękowa swojego dzieła Dumała? W których momentach słyszymy muzykę, jakim obrazom ona towarzyszy? ${ }^{23}$;

- uwzględnianiem fonetycznych środków stylistycznych w czasie analizy i interpretacji tekstów (między innymi określanie ich funkcji i efektów), np.:

${ }^{20}$ J. Kopciński: Przeszłość to dziś. Literatura, język, kultura. 3 klasa technikum i liceum. Warszawa 2014, s. 89.

${ }^{21}$ A. Łuczak, A. Murdzek: Język polski. Między nami 4. Gdańsk 2017, s. 292.

${ }^{22}$ E. Paczoska: Przeszłość to dziś. Literatura, język, kultura. 2 klasa technikum i liceum. Część 1. Warszawa 2013, s. 194.

${ }^{23}$ K. Budna, J. Manthey: Język polski 4. Podręcznik dla szkót ponadgimnazjalnych. Ksztatcenie kulturowo-literackie i językowe. Zakres podstawowy i rozszerzony. Pozytywizm. Młoda Polska. Gdynia 2014, s. 118. 
Przeczytaj utwór głośno, zwracając uwagę na jego linię intonacyjna. $W$ których wersach intonacja rośnie, w których opada (zwróć uwage na znaki graficzne i dlugość wersów)? Wskaż miejsca, w których intonacja wierszowa rozmija się ze zdaniowa. Z jakim ruchem kojarzyć można takie „rozkotysanie" tekstu? W jaki sposób podkreśla on nastrój utworu? ${ }^{24}$;

— analizą porównawczą utworów muzycznych i poetyckich, np.:

Jeśli masz możliwość, wystuchaj muzycznej adaptacji wiersza Białoszewskiego w wykonaniu Ewy Demarczyk lub Justyny Steczkowskiej. Co wiersz zyskuje, a co traci w wersji muzycznej? Jakie elementy tekstu sa podkreślone przez melodię, tempo, udziat instrumentów?25.

Co prawda, praca nad słuchaniem na poziomie dźwięku skupia się na wyodrębnianiu, analizowaniu i intepretowaniu samych dźwięków, lecz warto pamiętać, że czynności te przyczyniają się do głębszego rozumienia tekstów.

Drugi poziom słuchania rozwijany w edukacji polonistycznej, a zatem na poziomie tekstu, obejmuje wszelkie działania ucznia, których podstawą jest tekst. W jego obrębie proponuję wyróżnić słuchanie poznawcze, służące rozumieniu tekstu, oraz słuchanie opiniujące, polegające na krytycznej analizie i ocenie wypowiedzi.

Pierwszy rodzaj słuchania, czyli słuchanie poznawcze, polega na percepcji tekstu zarówno na poziomie globalnym, jak i lokalnym. Słuchanie globalne kształci się przez uczenie:

— określania tematu, głównej myśli tekstu (rozumienie dosłowne lub interpretacyjne), np.:

Jaki jest — Twoim zdaniem — sens filmu Monty Pythona? ${ }^{26}$;

— rozpoznawania gatunku i jego specyfiki, np.:

Do jakiego gatunku filmowego należy dzieło Petersena? Uzasadnij swój wybór ${ }^{27}$;

${ }^{24}$ A. Nawarecki, D. Siwicka: Przeszłość to dziś. Literatura, język, kultura. 1 klasa technikum i liceum. Część 2. Warszawa 2012, s. 75.

${ }^{25}$ W. Bobiński: Świat w słowach i obrazach 3. Język polski. Podręcznik do gimnazjum. Warszawa 2014, s. 259.

${ }^{26}$ M. Chmiel, E. Kostrzewa: Ponad stowami..., s. 183.

${ }^{27}$ Ibidem, s. 61. 
- wskazywania intencji, funkcji lub efektów komunikacyjnych tekstów kultury, np.:

Wystuchaj dwu interpretacji glosowych utworu Jeremiego Przybory, a następnie wykonaj zadania. Przyporzadkuj stownictwo nazywajace postawe osoby mówiacej (oburzenie, złość, bunt, kpinę, zdziwienie, niedowierzanie): osoba mówiaca w interpretacji 1./w interpretacji 2 . wyraża... ${ }^{28}$;

— omówienia kontekstu komunikacyjnego wypowiedzi (między innymi scharakteryzowanie relacji nadawczo-odbiorczych), np.:

Wystuchaj nagrania na stronie internetowej. Następnie ustalcie, które z nich prowadza wasi rówieśnicy, a które sa rozmowami z osobami dorostymi ${ }^{29}$.

— wyrażenia własnych przeżyć związanych z odbiorem utworów lirycznych (tzw. wstępne rozpoznanie) lub muzycznych, np.:

Wystuchaj recytacji wiersza Czestawa Miłosza. Określ nastrój utworu ${ }^{30}$.

Wystuchajcie na lekcji dowolnego utworu zaliczanego do muzyki wspótczesnej i opowiedzcie o swoich wrażeniach ${ }^{31}$.

Kolejne typy słuchania poznawczego, czyli słuchanie lokalne i słuchanie selektywne, dotyczą szczegółowego rozumienia tekstu i obejmują identyczne szczegółowe sprawności, np.: rozpoznawanie nadawcy i odbiorcy tekstu, selekcję i hierarchizację informacji czy też przytaczanie fragmentów wypowiedzi. Różnica między nimi polega na samodzielności odbiorcy lub jej braku w pracy $\mathrm{z}$ tekstem mówionym. Podczas słuchania lokalnego uczeń zwraca uwagę i opracowuje składniki wypowiedzi, które zostały wskazane w instrukcji (poleceniu), np.:

[1] Wystuchaj legendy czytanej przez nauczyciela. W trakcie stuchania legendy wynotuj informacje potrzebne do udzielenia odpowiedzi na poniższe pytania:

${ }^{28}$ A. Łuczak, A. Murdzek: Język polski. Między nami 6. Gdańsk 2014, s. 90.

${ }^{29}$ Wśród znajomych $i$ przyjaciół. https://gwo.pl/strony/2736/seo_link:wsrod-znajomych-iprzyjaciol [data dostępu: 18.03.2020]. Zadanie interaktywne skorelowane z podręcznikiem Między nami 4 (dla klasy IV).

${ }^{30}$ M. Derlukiewicz: Stowa na start! Podręcznik do ksztatcenia literackiego i kulturowego dla klasy szóstej szkoły podstawowej. Warszawa 2015, s. 21.

${ }^{31}$ J. Kościerzyńska, M. Chmiel, M. Szulc, A. Gorzałczyńska-Mróz: Nowe stowa na start..., s. 73. 
Z jakim regionem Polski jest związana legenda „Bursztynowa korona"?

Kiedy się rozgrywaty ukazane wydarzenia?

Kim byt Mikołajek?

Kim była dziewczyna, która okradt Mikołajek?

Kim byt sędzia Mikotajka?

W jaki sposób stornia (mała flądra) i jaskótka pomogły chłopcu uniknać najsroższej kary?

Wjaki sposób chłopiec zostat ukarany? $?^{32}$.

Słuchanie selektywne z kolei polega na samodzielnym wyborze informacji, które później posłużą do różnych celów, np.:

[2] Oprócz sposobów na walkę z nieoczekiwana złościa warto również poznać recepty na radzenie sobie ze stresem. Znajdź na portalu YouTube [czytaj: jutjub] film zatytułowany ,Jak pokonać stres?”, udostępniony na kanale 'tvszkola'. Następnie ułóż listę porad, które pomoga w walce ze stresem. Na koniec dodaj swój własny sprawdzony sposób na radzenie sobie ze zdenerwowaniem ${ }^{33}$.

W wypadku doskonalenia słuchania lokalnego adresat polecenia [1] zostaje dokładnie poinformowany, na jakich elementach wypowiedzi powinien się skupić. Z kolei podczas pracy nad słuchaniem selektywnym [2] uczeń nakłaniany jest do samodzielnego myślenia i wyboru niezbędnych informacji, które zostaną praktycznie wykorzystane, np. podczas tworzenia instrukcji. Słuchanie poznawcze selektywne jest umiejętnością bardziej zaawansowaną niż słuchanie lokalne, gdyż wymaga większego zasobu wiedzy, zaawansowanych umiejętności percepcyjnych oraz praktyki w słuchaniu. Warto również dodać, że dla słuchania poznawczego charakterystyczne są dwa sposoby wykorzystania informacji zawartych w tekście, tzn. odtwórczy [1] — efektem percepcji słuchowej jest odtworzenie usłyszanych informacji, i twórczy [2] — umiejętność odbioru słuchowego weryfikuje się w twórczych działaniach językowych uczniów ${ }^{34}$.

Drugi rodzaj słuchania na poziomie tekstu, słuchanie opiniujące, obejmuje dwa typy percepcji słuchowej: krytyczną i oceniającą. Słuchanie krytyczne polega na poddaniu ocenie tego, co zostało usłyszane. Podobnie jak w trakcie czytania krytycznego, podczas pracy nad słuchaniem krytycznym uczeń doskonali umiejętność analizy odebranej wypowiedzi z różnych perspektyw,

${ }^{32}$ A. Łuczak, A. Murdzek: Język polski..., s. 291.

${ }_{33}$ M. Derlukiewicz: Stowa na start!..., s. 31.

${ }^{34} \mathrm{~W}$ tym przypadku kształcone są sprawności receptywno-produktywne. Zob. M.U. Chyb: Sprawności receptywno-produktywne w ksztatceniu sprawności słuchania. „Kształcenie Językowe" 2017 , t. 15 (25), s. 27-39. 
oceny zawartych w niej danych oraz syntetyzowania i wyciągania wniosków ${ }^{35}$. W kształceniu polonistycznym słuchanie krytyczne doskonali się między innymi podczas pracy nad:

— analizą gatunków medialnych, np.:

Obejrzyj w telewizji debatę lub dyskusję z udziatem polityków. Który z uczestników lepiej - Twoim zdaniem - przekonywat do swoich racji i jakimi środkami się postużyt, aby ten cel osiagnaci ${ }^{36}$.

— analizą przekazów medialnych, np.:

Postuchaj jednego dnia kilku radiowych i telewizyjnych serwisów informacyjnych. Zanotuj wiadomości, które powtarzaja się w obu mediach. Jak o wybranym wydarzeniu mówi się w radiu, a jak - w telewizji? ${ }^{37}$.

Głównym celem doskonalenia słuchania krytycznego jest uwrażliwienie ucznia na środki językowe i pozajęzykowe, z jakich korzystają nadawcy w celu oddziaływania na odbiorców. Najważniejsze pytania ukierunkowane na krytyczny odbiór komunikatów ${ }^{38}$ (ustnych i pisemnych) to: Kim jest autor? Jakie są jego kompetencje? Jaka jest jego opinia moralna i społeczna? W jakim celu i w jaki sposób się wypowiada? Co chce osiągnąć? Czy jest obiektywny, czy tendencyjny? Jakie argumenty przywołuje (rzeczowe, emocjonalne itp. ${ }^{39}$ ? Ponadto ćwiczenia rozwijające słuchanie krytyczne mają na celu wykształcenie w uczniu tzw. dojrzałości krytycznej, na którą składają się następujące elementy: sceptycyzm - potrzeba sprawdzenia tego, co się słyszy; obiektywizm zdolność odsunięcia na drugi plan własnych przekonań, poglądów, sympatii i niechęci; wiedza ogólna i specjalna, której źródłem jest szerokie oczytanie i doświadczenie życiowe; wyrobienie logiczne — umiejętność ścisłego, a zarazem poprawnego myślenia ${ }^{40}$.

Słuchanie oceniające jest najbardziej zaawansowaną sprawnością, gdyż jego podstawę stanowią wszystkie do tej pory wymienione typy percepcji słuchowej, tj. słuchanie fonematyczne (analityczne i interpretacyjne), poznawcze

${ }^{35}$ E. Malmquist: Nauka czytania w szkole podstawowej. Tłum. A. Thierry. Warszawa 1987, s. 155.

${ }^{36}$ M. Chmiel, E. Kostrzewa: Ponad stowami..., s. 54.

37 W. Herman: Stowa na czasie. Podręcznik do ksztatcenia językowego z ćwiczeniami dla klasy trzeciej gimnazjum. Straszyn k. Gdańska 2011, s. 122.

38 Pierwsze wymienione pytania odnoszą się przede wszystkim do percepcji poznawczej tekstu. Pełnią funkcję wprowadzenia do krytycznej oceny wypowiedzi.

${ }^{39}$ Zob. F. Król: Sztuka czytania. Warszawa 1982, s. 162-164.

${ }^{40}$ Zob. ibidem, s. 161. 
(globalne, lokalne/selektywne), opiniujące (krytyczne). Słuchanie oceniające na lekcjach języka polskiego doskonali się w ramach pracy nad:

— recytacją utworów literackich, np.:

Pracując w grupach, przygotujcie głośne wykonanie wiersza Brylla tak, aby oddać nastrój pieśni greckiego chóru. Możecie wprowadzić partie chóralne i wygłaszane indywidualnie, podkład dźwiękowy, powtarzanie niektórych wersów. Nastęnie zaprezentujcie swoje wykonania i oceńcie, które zrobiło największe wrażenie ${ }^{41}$,

— recenzją filmu/spektaklu teatralnego, np.:

Napisz recenzję, w której ocenisz następujące elementy filmu: scenografię, kostiumy, muzykę, zdjęcia, montaż, reżyserię, grę aktorów, efekty specjal$n e^{42}$

— przemówieniem, np.:

Obejrzyjcie w internecie przemówienie Mai Włoszczowskiej pt. „Prosta recepta na wygrywanie " [...], a następnie dokonajcie jego analizy. Uwzględnijcie odpowiedzi na nastepujace pytania:

- Czy cel mowy byt czytelny?

- Czy język i styl przemówienia byly dostosowane do tematu i odbiorców?

- Jakich chwytów użyła sportsmenka, żeby przyciagnać uwagę stuchaczy?

- Czy Włoszczowska zastosowata odpowiednia mowę ciała i artykulację, czy utrzymała kontakt z odbiorcami?

- Czy w zakończeniu znalazło sie jasne i precyzyjne podsumowanie catości ${ }^{43}$;

- słuchowiskiem radiowym, np.:

Przygotujcie stuchowisko radiowe na podstawie scenariusza Jerzego Górzańskiego. Utwórzcie grupy i zadbajcie o odpowiedni podziat ról. Wybierzcie spośród siebie aktorów, osoby odpowiedzialne za dobór muzyki oraz efektów dźwiękowych. Zarejestrujcie stuchowisko na plycie CD. Od-

${ }^{41}$ K. Mrowcewicz: Przeszłość to dziś. Literatura, język, kultura. 1 klasa technikum i liceum. Część 1. Warszawa 2012, s. 59.

${ }_{42}$ M. Chmiel, E. Kostrzewa: Ponad stowami..., s. 61.

${ }^{43}$ J. Kościerzyńska, M. Chmiel, M. Szulc, A. Gorzałczyńska-Mróz: Nowe stowa na start!..., s. 165. 
twórzcie gotowe nagrania w klasie i ustalcie, czyja wersja byta najbardziej profesjonalna ${ }^{44}$;

— tworzeniem ustnej wypowiedzi argumentacyjnej, np.:

Wygtoś swoja wypowiedź. Postaraj się nie korzystać z przygotowanego wcześniej konspektu. Określ, jak jego brak wplywa na jakość wystapienia, jasność przekazu, uporzadkowanie treści, tempo i swobodę mówienia ${ }^{45}$.

Uczeń podczas słuchania wypowiedzi zwraca uwagę na treść przekazu jego główny sens i zawarte w nim szczegółowe informacje, oraz sposób jego wypowiadania (operowanie głosem, mimiką, postawą ciała itp.), a następnie poddaje tekst ocenie ze względu na różne kryteria i formułuje opinię na jego temat. Dlatego też ten typ słuchania ma charakter twórczy ${ }^{46}$, gdyż rozwija sprawność myślenia, uczy prezentowania własnego zdania i argumentowania swojej opinii. Wymaga od uczniów dużego zasobu wiedzy oraz umiejętności analityczno-oceniających.

Zaprezentowana typologia odzwierciedla złożoność procesu (kształcenia) odbioru tekstów mówionych w języku polskim jako ojczystym. Mimo to obecnie obowiązująca podstawa programowa marginalizuje kwestię rozwijania percepcji słuchowej w szkole. Jedynie w wymaganiach ogólnych dla szkół podstawowych (klas IV-VIII) i ponadpodstawowych zaznaczono, że lekcje języka ojczystego w zakresie kształcenia językowego mają mieć na celu między innymi: ,[...] kształcenie umiejętności porozumiewania się (słuchania, czytania, mówienia i pisania) w różnych sytuacjach oficjalnych i nieoficjalnych [... $]^{347}$, a także „wzbogacanie umiejętności komunikacyjnych [...]"48. Zaproponowana typologia może więc stanowić pomoc dla nauczycieli, którzy są świadomi ko-

${ }^{44}$ M. Chmiel, P. Doroszewski, W. Herman, Z. Pomirska: Stowa na czasie. Podręcznik do kształcenia literackiego i kulturowego dla klasy trzeciej gimnazjum. Straszyn k. Gdańska 2011, s. 121.

${ }^{45}$ M. Chmiel, A. Równy: Ponad stowami. Podręcznik do języka polskiego dla liceum i technikum. Zakres podstawowy i rozszerzony. Klasa 2. Część 1. Warszawa 2014, s. 188.

${ }^{46}$ E. Malmquist: Nauka czytania..., s. 155.

${ }^{47}$ Rozporządzenie Ministra Edukacji Narodowej z dnia 14 lutego 2017 r. w sprawie podstawy programowej wychowania przedszkolnego oraz podstawy programowej kształcenia ogólnego dla szkoły podstawowej, w tym dla uczniów z niepełnosprawnością intelektualną w stopniu umiarkowanym lub znacznym, kształcenia ogólnego dla branżowej szkoły I stopnia, kształcenia ogólnego dla szkoły specjalnej przysposabiającej do pracy oraz kształcenia ogólnego dla szkoły policealnej. http://dziennikustaw.gov.pl/du/2017/356 [data dostępu: 18.03.2020].

48 Rozporządzenie Ministra Edukacji Narodowej z dnia 30 stycznia 2018 r. w sprawie podstawy programowej kształcenia ogólnego dla liceum ogólnokształcącego, technikum oraz branżowej szkoły II stopnia. http://www.dziennikustaw.gov.pl/DU/2018/467 [data dostępu: 18.03.2020]. 
nieczności pracy nad percepcją słuchową w szkole. To od nich zależy, na jaki typ słuchania zwrócą uwagę, jakie szczegółowe sprawności percepcyjne będą doskonalić podczas wykonywania konkretnych zadań, innymi słowy — w jaki sposób będą aktywizować słuchanie na lekcjach. Nie budzi wątpliwości fakt, że nauka percepcji słuchowej jest koniecznym elementem współczesnej edukacji. Nie tylko wpływa na efektywność przyswajania wiedzy przez uczniów na wszystkich lekcjach w szkole ${ }^{49}$ — warunkuje słuchanie naturalne, ale także, co najważniejsze, przygotowuje przyszłych absolwentów szkół do świadomego funkcjonowania w obowiązującym systemie społeczno-kulturowym, w którym dominuje bierna postawa komunikacyjna ${ }^{50}$.

\section{Bibliografia}

\section{Publikacje drukowane}

Aubert J.-L.: Naucz swoje dziecko stuchać. Odpowiedzi na pytania najczęściej zadawane przez rodziców. Tłum. A. Wróblewski. Warszawa 2007.

Chyb M.U.: Sprawności receptywno-produktywne w kształceniu sprawności stuchania. „Kształcenie Językowe" 2017, t. 15 (25), s. 27-39.

Dźwięki mowy. Program kształtowania świadomości fonologicznej dla dzieci przedszkolnych i szkolnych. Red. A. Mauer. Kraków 2009.

Howatt A., Dakin J.: Materiały do pracy w laboratorium językowym. Tłum. E. Moszczak. W: Kurs edynburski językoznawstwa stosowanego. T. 2: Techniki w językoznawstwie stosowanym. Red. J.P.B. Allen, S. Pit Corder, A. Davies. Warszawa 1983, s. 84-115.

Jańczyk G.: Ksztaltowanie sprawności językowych w gimnazjum. Pisanie, mówienie, stuchanie. Kraków 2002.

Komorowska H.: Metodyka nauczania języków obcych. Warszawa 1999.

Król F.: Sztuka czytania. Warszawa 1982.

Lipińska E.: Stuchanie - sprawność zaniedbywana. „Przegląd Polonijny” 1994, z. 4, s. 75-89.

Malmquist E.: Nauka czytania w szkole podstawowej. Tłum. A. Thierry. Warszawa 1987.

Mądry-Kupiec M.: Komunikacja werbalna nauczyciela i ucznia na lekcji. Kraków 2011.

Morreale S.P., Spitzberg B.H., Barge J.K.: Komunikacja między ludźmi. Motywacja, wiedza i umiejętności. Tłum. P. Izdebski, A. Jaworska-Surma, D. Kobylińska. Warszawa 2007.

${ }^{49}$ Warto w tym miejscu przytoczyć słowa Grażyny Jańczyk, która stwierdza, że „nie sposób [...] posługiwać się np. elementami wykładu bez sprawdzenia, w jakim stopniu uczeń umie słuchać, oraz bez ciągłego usprawniania tej umiejętności w ramach stosowanej metody. I dotyczy to w równym stopniu polonisty, co geografa czy historyka”. G. Jańczyk: Kształtowanie sprawności językowych w gimnazjum. Pisanie, mówienie, stuchanie. Kraków 2002, s. 43.

50 Zob. A. Skudrzyk: Czy zmierzch kultury pisma? O synestezji i analfabetyzmie funkcjonalnym. Katowice 2005, s. 36-39. 
Nocoń J.: Polecenia i pytania w podręcznikach do nauki o języku. Opole 1997.

Skudrzyk A.: Czy zmierzch kultury pisma? O synestezji i analfabetyzmie funkcjonalnym. Katowice 2005.

Wojtczuk K.: Zachowania językowe nauczycieli w sytuacji lekcji szkolnej. Siedlce 1996.

\section{Źródła internetowe}

Rozporządzenie Ministra Edukacji Narodowej z dnia 14 lutego 2017 r. w sprawie podstawy programowej wychowania przedszkolnego oraz podstawy programowej kształcenia ogólnego dla szkoły podstawowej, w tym dla uczniów z niepełnosprawnością intelektualną w stopniu umiarkowanym lub znacznym, kształcenia ogólnego dla branżowej szkoły I stopnia, kształcenia ogólnego dla szkoły specjalnej przysposabiającej do pracy oraz kształcenia ogólnego dla szkoły policealnej. http://dziennikustaw.gov.pl/du/2017/356 [data dostępu: 18.03.2020].

Rozporządzenie Ministra Edukacji Narodowej z dnia 30 stycznia 2018 r. w sprawie podstawy programowej kształcenia ogólnego dla liceum ogólnokształcącego, technikum oraz branżowej szkoły II stopnia. http://www.dziennikustaw.gov.pl/DU/2018/467 [data dostępu: 18.03.2020].

W'́ród znajomych i przyjaciót. https://gwo.pl/strony/2736/seo_link:wsrod-znajomych-i-przyjaciol [data dostępu: 18.03.2020].

\section{Wykaz cytowanych podręczników szkolnych}

Bobiński W.: Świat w stowach i obrazach 3. Język polski. Podręcznik do gimnazjum. Warszawa 2014.

Budna K., Manthey J.: Język polski 4. Podręcznik dla szkół ponadgimnazjalnych. Kształcenie kulturowo-literackie i językowe. Zakres podstawowy i rozszerzony. Pozytywizm. Młoda Polska. Gdynia 2014.

Chmiel M., Doroszewski P., Herman W., Pomirska Z.: Słowa na czasie. Podręcznik do ksztatcenia literackiego i kulturowego dla klasy trzeciej gimnazjum. Straszyn k. Gdańska 2011.

Chmiel M., Kostrzewa E.: Ponad stowami. Podręcznik do języka polskiego dla liceum i technikum. Zakres podstawowy i rozszerzony. Klasa 1. Część 1. Warszawa 2012.

Chmiel M., Równy A.: Ponad stowami. Podręcznik do języka polskiego dla liceum i technikum. Zakres podstawowy i rozszerzony. Klasa 2. Czesść 1. Warszawa 2014.

Derlukiewicz M.: Stowa na start! Podręcznik do kształcenia literackiego i kulturowego dla klasy szóstej szkoły podstawowej. Warszawa 2015.

Herman W.: Stowa na czasie. Podręcznik do ksztatcenia językowego z ćwiczeniami dla klasy trzeciej gimnazjum. Straszyn k. Gdańska 2011.

Kopciński J.: Przeszłość to dziś. Literatura, język, kultura. 3 klasa technikum i liceum. Warszawa 2014.

Kościerzyńska J., Chmiel M., Szulc M., Gorzałczyńska-Mróz A.: Nowe słowa na start! Podręcznik do języka polskiego dla klasy ósmej szkoły podstawowej. Warszawa 2018.

Łuczak A., Murdzek A.: Język polski. Między nami 4. Gdańsk 2017.

Łuczak A., Murdzek A.: Język polski. Między nami 6. Gdańsk 2014. 
Mrowcewicz K.: Przeszłość to dziś. Literatura, język, kultura. 1 klasa technikum i liceum. Część 1. Warszawa 2012.

Nawarecki A., Siwicka D.: Przeszłość to dziś. Literatura, język, kultura. 1 klasa technikum i liceum. Częśś 2. Warszawa 2012.

Paczoska E.: Przeszłość to dziś. Literatura, język, kultura. 2 klasa technikum i liceum. Część 1. Warszawa 2013. 